
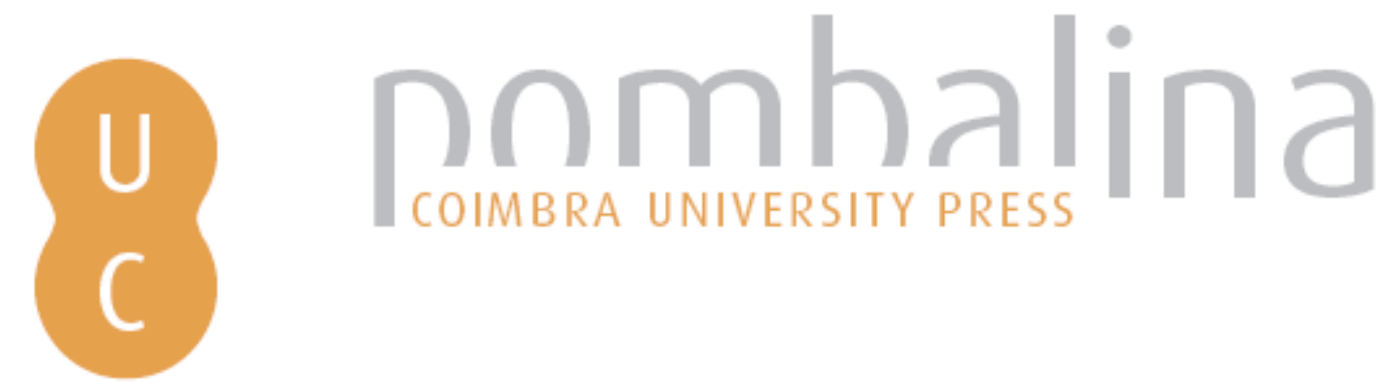

\title{
Protecting lives and property: testing tanker crew protection systems
}

$\begin{array}{ll}\text { Autor(es): } & \text { Bessell, Rachel; Nichols, David; Leonard, Justin; Cruz, Miguel G.; } \\ \text { Slijepcevic, Alen }\end{array}$

Publicado por: Imprensa da Universidade de Coimbra

URL

persistente: URI:http://hdl.handle.net/10316.2/44528

DOI: $\quad$ DOI:https://doi.org/10.14195/978-989-26-16-506_11

Accessed : $\quad$ 26-Apr-2023 13:50:41

A navegação consulta e descarregamento dos títulos inseridos nas Bibliotecas Digitais UC Digitalis, UC Pombalina e UC Impactum, pressupõem a aceitação plena e sem reservas dos Termos e Condições de Uso destas Bibliotecas Digitais, disponíveis em https://digitalis.uc.pt/pt-pt/termos.

Conforme exposto nos referidos Termos e Condições de Uso, o descarregamento de títulos de acesso restrito requer uma licença válida de autorização devendo o utilizador aceder ao(s) documento(s) a partir de um endereço de IP da instituição detentora da supramencionada licença.

Ao utilizador é apenas permitido o descarregamento para uso pessoal, pelo que o emprego do(s) título(s) descarregado(s) para outro fim, designadamente comercial, carece de autorização do respetivo autor ou editor da obra.

Na medida em que todas as obras da UC Digitalis se encontram protegidas pelo Código do Direito de Autor e Direitos Conexos e demais legislação aplicável, toda a cópia, parcial ou total, deste documento, nos casos em que é legalmente admitida, deverá conter ou fazer-se acompanhar por este aviso.

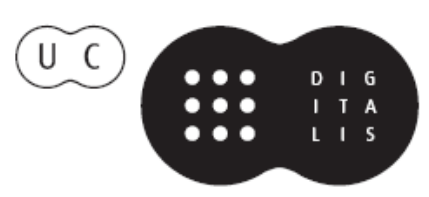




\section{ADVANCES IN}

\section{FOREST FIRE RESEARCH}

\section{8}

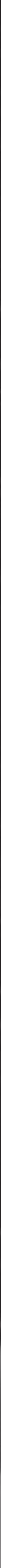




\title{
Protecting lives and property: testing tanker crew protection systems
}

\author{
Rachel Bessell*1; David Nichols ${ }^{1}$; Justin Leonard ${ }^{2}$; Miguel G. Cruz ${ }^{3}$; Alen Slijepcevic ${ }^{1}$ \\ ${ }^{1}$ Country Fire Authority. Victoria, Australia, \{r.bessell@cfa.vic.gov.au*\} \\ ${ }^{2}$ CSIRO Bushfire Research, Land and Water, Clayton, Australia \\ ${ }^{3}$ CSIRO Bushfire Behaviour and Risks, Land and Water, Canberra, Australia
}

\begin{abstract}
Vehicle entrapment and fire burn over is a life-threating situation for fire fighters. In Australia, significant crew protection research commenced following the 1998 Linton wildfire (in Victoria, Australia) where five CFA volunteers perished when their tanker was entrapped and burnt over. Since the Linton fire burn over, CFA crew protection research has aimed to reduce the probability of loss of life in a tanker burn over. This involves increasing the number of protection layers between fire fighters and the fire including: personal protective blankets, drop-down radiant heat shielding and water spray deluge systems with pump protection.

From 2004 to 2017, a series of experimental burns were conducted to test the safety of fire fighters in tankers. Initial system validation tests were conducted in a gas-fuelled flame front simulator at Mogo, New South Wales, Australia. Subsequently, successful field validation tests were conducted in forested environments at low intensities. This successful testing resulted in all new CFA medium to heavy tankers (upwards of 2000 litre water capacity) being fitted with a crew protection system from 2006, and all existing tankers retro-fitted from 2013.

Due to restricted water capacity, ultra-light tankers (less than 800 litre water capacity) need a different system. Two new water enhancing methods were designed and tested, a Compressed Air Foam System (CAFS) and a polymer gel system.

In March 2014, the medium tanker and gel ultra-light crew protection systems were tested in grass fire field experiments in Wangaratta, Victoria; both crew protections systems met survivability objectives.

In March 2017, a high intensity experimental fire was conducted in Brucknell, Victoria, in order to validate the crew protection systems retrofitted onto a CFA medium tanker and to test the two new water enhancing methods on two ultra-light tankers. The Brucknell fire had an average intensity of $19,000 \mathrm{~kW} / \mathrm{m}^{2}$ (twice that of the Linton wildfire) with a peak intensity of $31,000 \mathrm{~kW} / \mathrm{m}^{2}$. All crew protection systems met survivability objectives.

Ten years since the 1998 Linton wildfire, on 7 February 2009, Victoria experienced unprecedented extremes in fire weather resulting in the Black Saturday wildfires. 173 people perished, over 2000 properties were lost and over 430,000 hectares were burnt. Of the hundreds of fire fighting vehicles involved, a number were caught out in burn over situations, yet no fire fighters were seriously injured. This remarkable result can be credited to the tanker crew protection systems.
\end{abstract}

Keywords: firefighter safety, vehicle crew protection, vehicle entrapment, burn over

\section{Introduction}

'It must be understood that safety, in the environment of a wildfire can be a complex issue, which needs constant attention and vigilance, by those agencies responsible for its management.'

Extract from the Corners Court of Victoria (2002), Inquest into the Linton Wildfire, page 572.

Wildfires are a common phenomenon in the state of Victoria, Australia. In trying to control these fires, the Country Fire Authority (CFA) has experienced multiple firefighting tanker burn overs resulting in serious injuries and fatalities. Two of the most serious instances in Victoria were (1) during the Ash Wednesday wildfires in 1983 where twelve firefighters were killed during a burn over 
of two tankers in Belgrave South/Beaconsfield Upper (CFA, 1983) and (2) in the Linton wildfire in 1998 where a tanker became entrapped and burnt over killing all five fire fighters (CFA and NRE, 1999). In both of these instances, fire fighters were working away from the edge of the fire and were caught off guard with a sudden change in wind direction and fire behaviour. Known as the 'dead-man zone', fire fighters have very little time to egress or seek refuge before the fire overwhelms them (Cheney et al, 2001).

Since these tragedies, CFA made substantial safety improvements to its fire fighting tanker fleet to ensure the safety and protection of its fire fighters. CFA tanker crew protection systems are designed to increase the level of protection by maintaining the integrity of the cabin, particularly the windows, to reduce the temperatures inside the cabin and increase the number of protective layers between the fire fighters and the fire.

Over the initial stages of the crew protection system testing (pre-2010), various system elements were designed, tested and refined. Some of these improvements include: personal protective blankets, low level water indicators, water spray deluge systems, internal cabin drop down radiant heat shielding curtains, additional heat shielding around the water pump system and vulnerable tanker components, a reduction of plastic material on the external surfaces of the tankers, metal air cleaner filters, flame resistant hose and cabling, upgraded communication systems and all diesel engines. This work has resulted in the installation of crew protection systems on the entire fleet of CFA medium and heavy tankers. Crew protection systems have been installed on all newly built tankers since 2006 while all older tankers were retro-fitted prior to the 2013-2014 summer fire season.

The focus of this paper is to highlight the crew protection system validation and testing that has occurred since 2013. To validate the crew protection systems on a retro-fitted medium (2000L) tanker, the tanker was burnt in experimental fires in both grass and forest, and at different intensities in a gaspropelled flame front simulator. Additionally, two ultra-light tankers (less than 500L capacity) systems have been designed and tested in experimental fires and in the gas-propelled flame front simulator.

\section{Experimental burns}

From 2004 to 2017, multiple experimental burns have been conducted in Victoria and New South Wales (NSW) to test the safety of fire fighters in tankers. As there are no occupational exposure standards that exist for fire smoke, air toxic tenability levels have been determined using Safe Work Australia short-term (15-minute) exposure guidelines (Leonard et al., 2017). Also there are no guidelines for survivability levels, they have been estimated at five times the tenability limits. The respirable particle survivability limit is set at $30 \mathrm{mg} / \mathrm{m}^{3}$, however fire fighters are often exposed to much higher levels during prescribed burning actitivies (Reisen and Brown, 2009). A criterion has been used for the studies as it is important to identify that some firefighters may be more susceptable to fire smoke than others at these respirable particle levels. Different strategies, such a respiratory protection could be established to minimise health risks (Leonard et al., 2017).

Pre-2010, crew protection systems installed on a medium tanker had undergone repeatable tests at the New South Wales Rural Fire Service (NSW RFS) Hot Fire Training Facility south of Mogo, NSW, Australia. The flame front simulator design and subsequent testing was as described by Nichols (2010). During this testing the medium tanker met crew survivability objectives at $5000 \mathrm{~kW} / \mathrm{m}^{2}$.

Field testing was also conducted at Tumbarumba, NSW in February 2004. Of these two experimental fires, both fell well below the intended intensity objectives, however validated the crew protection system at medium intensities, less than $2000 \mathrm{~kW} / \mathrm{m}^{2}$ (Nichols, 2010).

In order to validate the crew protection system installed on the fleet of CFA medium and heavy tankers, further field testing was conducted in both grass and forest environments. 


\subsection{Grass fire - Wangaratta, Victoria, March 2014}

The aim of the Wangaratta tests were to see how the medium tanker and ultra-light gel crew protection systems performed under grass fire conditions. The tests were conducted in March 2014 on a rural property south of Wangaratta, Victoria. The tankers were burnt in seperate experiments, within grass plots of $35 \times 35 \mathrm{~m}$.

The full details of the experiment are detailed in Leonard et al. (2014). Temperatures both inside and outside the cabin were measured, and radiometers were utilised to determine fire intensities. Air toxic exposures were also measured. The ambient temperature during the testing was between 27 and $30^{\circ} \mathrm{C}$. Unfortuntely on the day conditions were not optimal to conduct high intensity grass fires, due to overnight due formation and light and variable winds (Cruz et al., 2014).

The medium tanker tests were replicated (two experiments) as the wind shifted and the headfire did not directly impact the tanker in the first experiment. During the second test, flame heights of $2.5 \mathrm{~m}$ were recorded, with the flame front directly impacting the tanker. The water deluge spray system was activated from the start of the test, and it took the flames approximately 45 seconds to reach the tanker (Leonard et al, 2014). Maximum radiant heat, recorded on the passenger side door was $25 \mathrm{~kW} / \mathrm{m}^{2}$. The inside air temperature remained unchanged throughout the test at $40^{\circ} \mathrm{C}$. The peak temperature recorded on the outside passenger door was around $180^{\circ} \mathrm{C}$ noting that this temperature is within the water mist spray and hence does not reflect the true flame temperature (Leonard et al., 2014). Air toxics were only measured for the first medium tanker experiment, and recorded values were well below tenability and survivability thresholds.

Overall there was no reported damage to the tanker, with the spray system providing adequate protection to the tanker as well as grass surrounding and beneath the tanker (Figure 1).

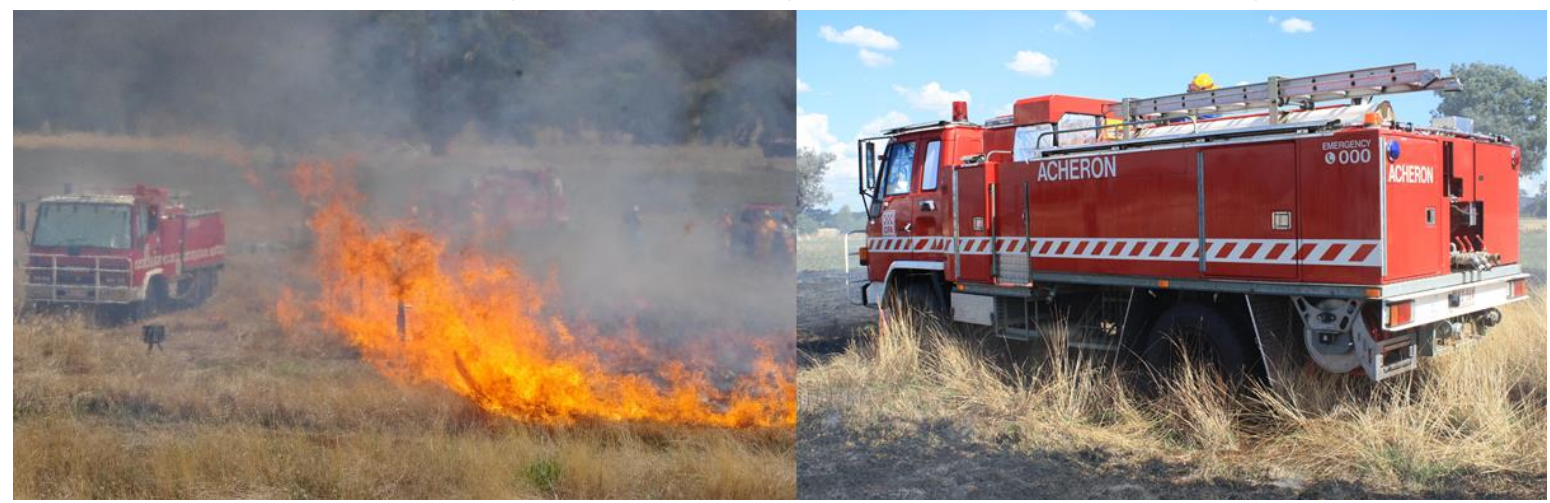

Figure 1 - CFA Medium tanker during and following the second experimental burn, Wangaratta, Victoria.

The gel ultra-light tanker test was observed to be the most severe of the three experiments conducted on the day. Time from ignition to impact was approximately 40 seconds, and flame heights of $3 \mathrm{~m}$ were observed. The polymer gel was pre-applied before ignition. The radiant heat profile peak was $95 \mathrm{~kW} / \mathrm{m}^{2}$ on the passenger side. Outside air temperature peak was at $330^{\circ} \mathrm{C}$, yet the inside air temperature was a constant $40^{\circ} \mathrm{C}$. No in-cabin pollutant concentrations exceeded the tenability or survivability thresholds. There was no significant damage to the tanker (Leonard et al., 2014).

\subsection{Forest fire - Brucknell, Victoria, March 2016}

An experimental burn block of 0.9 ha at Brucknell, Victoria was selected for the forest fire experiment. The block was north facing, had a $7^{\circ}$ slope, and a fuel complex appropriate to achieve a high intensity fire. The overstorey was dominated by Stringybark eucalypts and had not been burnt since the Ash Wednesday wildfires 33 years earlier. In the days preceeding the burn, a number of 
small prescribed burns were conducted in mild conditions surrounding the burn block to limit the likelihood of the experimental fire escaping.

The objectives of the experiment were:

(i) To conduct a high intensity experimental fire of at least $10,000 \mathrm{~kW} / \mathrm{m}^{2}$ to replicate conditions of the 1998 Linton wildfire.

(ii) Field test the following CFA crew protection systems:

a. A retro-fitted crew protection system on a medium tanker (2000L capacity)

b. A polymer gel delivery system on an ultra-light tanker (400L capacity)

c. A Compressed Air Foam Systems (CAFS) on an ultra-light tanker (400L capacity)

A full report on the fuels, weather and fire behaviour aspects of the Brucknell experimental burn is documented in Cruz et al., (2016).

The Brucknell fire was ignited at 12:59:00 on 17 March 2016. The preceeding months of January and February were drier than usual. The nearby weather stations had an average Keetch-Byram Drought Index of 132, and a Drought Factor of 10. The prevalent weather conditions at 13:00 were:

Temperature $=33^{\circ} \mathrm{C}$

Relative Humidity $=25 \%$

$10 \mathrm{~m}$ open wind speed $=33 \mathrm{~km} / \mathrm{h}$ (average); gusts to $50 \mathrm{~km} / \mathrm{h}$

These conditions resulted in a Forest Fire Danger Index (FFDI) of 34.5 representating a Very High Fire Danger Rating.

The fireline was ignited with two pairs of two igniters with hand-held drip torches, lighting an approximately $100 \mathrm{~m}$ long ignition line. A high intensity flame front developed right after igniton, and a psuedo-steady state rate of spread was observed after $20 \mathrm{~m}$. Flame heights estimated to be $5-6 \mathrm{~m}$, with bark fuels allowing it to climb $10 \mathrm{~m}$ up tree trunks. There were multiple spot fire ignitions occuring in front of the vehicles. It took 3.5 minutes from ignition for the fire to reach the tankers (Figure 2). Water sprays on the medium tanker, and CAFS on one of the ultra-light tankers were activated 2 minutes after ignition. The gel delivery system was still yet to be refined, as such the gel was pre-applied to the ultra-light tanker approximately 20 minutes before ignition. Considering the estimated fuel consumed, the average rate of spread was $31 \mathrm{~m} /$ minute, which gives a fireline intensity of approximately $19,000 \mathrm{~kW} / \mathrm{m}^{2}$ (Cruz et al., 2016).

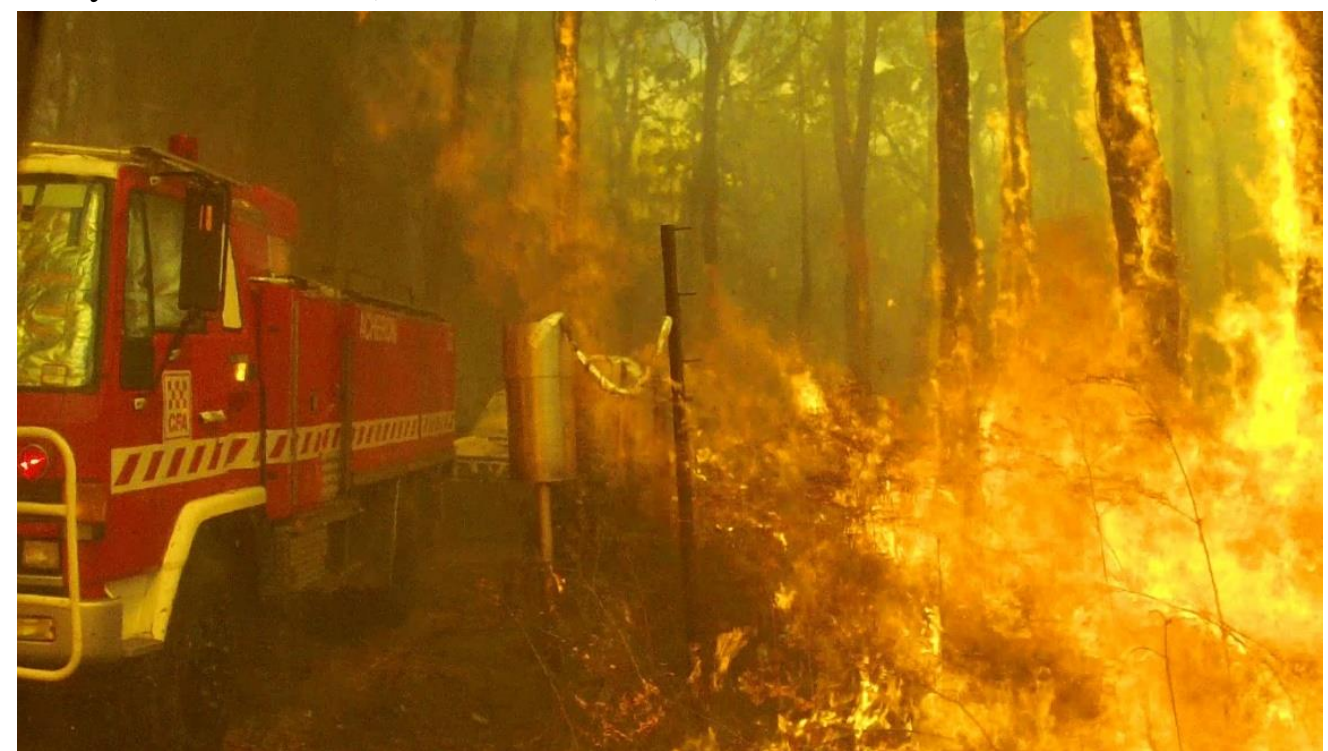

Figure 2. Brucknell experimental burn impacting the CFA medium tanker, CAFS and Gel ultra-light tankers 
A full report of the tanker tenability and survivability objectives is documented by Leonard et al., (2016). The internal cabins of all three tankers were instrumented for temperature and air toxics.

\subsubsection{Gel protected ultra-light tanker results}

The gel ultra-light tanker had a radiant heat peak of $60 \mathrm{~kW} / \mathrm{m}^{2}$. Outside air temperature above the passenger door peaked at $350^{\circ} \mathrm{C}$, yet the internal air temperature remained unchanged at $33^{\circ} \mathrm{C}$ until after the fire front had passed around four minutes from start of the test. Fourteen minutes after ignition the passenger front wheel showed elevated temperatures consistent with tyre combustion. From air toxicity results, the cabin exceeded the carbon monoxide tenability limit (of 100ppm) 4.5 minutes after direct flame contact. Respirable particle concentrations exceeded survivability concentrations two minutes after flame contact. Volatile Organic Compounds (VOC) levels were well below detection levels 30 seconds after flame impact; however 3.5 minutes later, aromatic VOC contentrations were much higher than external concentrations and chlorinated VOCs were observed indicating polyvinyl chloride (PVC) in the gel ultra-light cabin had ignited (Leonard et al., 2016).

\subsubsection{CAFS protected ultra-light tanker results}

No radiant heat measurements were taken from the CAFS ultra-light tanker due to lack of an effective system to protect the radiometer from the foam. Outside air temperature near the cabin peaked between 200 and $250^{\circ} \mathrm{C}$. The inside air temperature remained unchanged at $38^{\circ} \mathrm{C}$ until after the fire front has passed. Temperature gradually increased over time, but remained below $60^{\circ} \mathrm{C}$ eight minutes after the front has passed. There was no significant observable damage to the tanker. No tenablility or survivablility criteria were exceeded in the CAFS ultra-light tanker cabin except for smoke ingress (Leonard et al., 2016).

\subsubsection{Medium tanker results}

The radiant heat peaked at $35 \mathrm{~kW} / \mathrm{m}^{2}$, four minutes after ignition. The outside temperature of the vehicle dropped once the spray system was turned on, and increased rapidly when the fire front reached the tanker (depicted in Figure 2), at $300^{\circ} \mathrm{C}$. The inside air temperature remained unchanged at $33^{\circ} \mathrm{C}$ until after the fire front had passed, then it slowly increased over time as the water spray system was completed, but remained around $50^{\circ} \mathrm{C}$. The crew compartment in the rear of the tanker started to rise following the fire front reaching $70^{\circ} \mathrm{C}$ for 90 seconds before decling in line with the internal temperatures. There was no visible damage to the tanker with the water deluge spray system also protecting the remnant fuels surrounding and beneath the tanker (Figure 3). No tenablility or survivablility criteria were exceeded in the medium tanker cabin except for smoke ingress (Leonard et al., 2016).

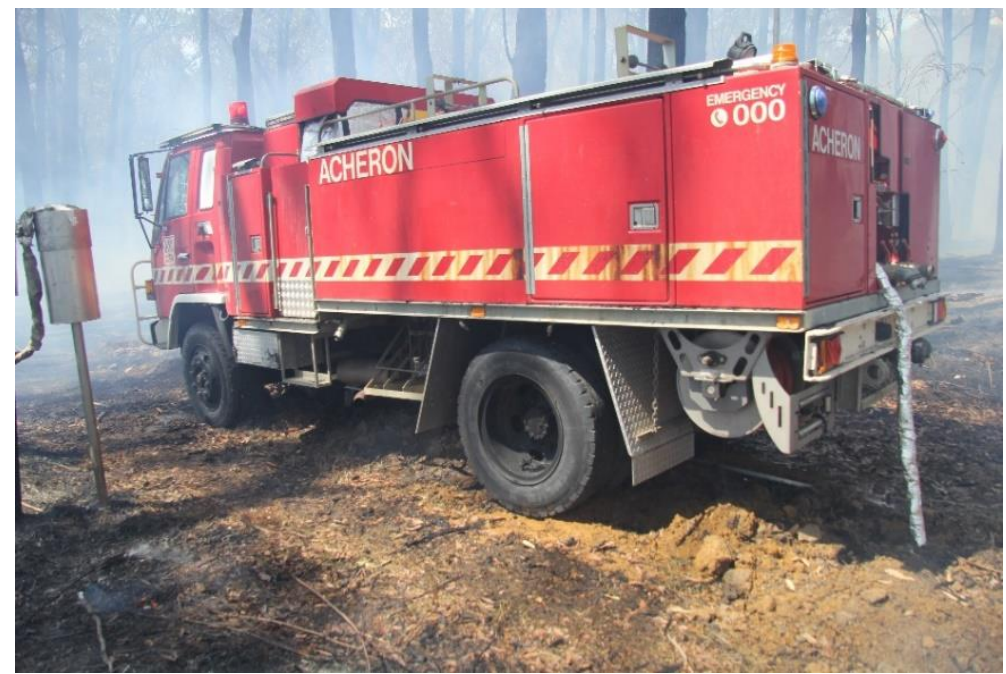

Figure 3. CFA Medium tanker after Brucknell experimental burn 


\subsection{Mogo - flame front simulator, November 2017}

In Mogo, NSW, in November 2017, the medium tanker and the CAFS protected ultra-light tanker were tested for different objectives. The flame front simulator test of the medium tanker was performed at three different intensity levels to understand how the system would perform at elevated exposure levels. The full report of this experiment is documented in Leonard et al., (2018).

The objective of the CAFS ultra-light tanker experiment was to test the survivability of the ultralight tanker with the CAFS crew protection system installed at a simulated fireline intensity of $5000 \mathrm{~kW} / \mathrm{m}^{2}$. The full report of this experiment is documented in Leonard et al., (2017).

The gel protected ultra-light tanker had previously been tested at Mogo and passed tenability and survivability objectives (Leonard et al., 2013).

\subsubsection{Medium tanker tests}

The medium tanker retrofitted with the current CFA crew protection system was subject to three experimental burns under three different intensities: $10,000 \mathrm{~kW} / \mathrm{m}^{2}, 15,000 \mathrm{~kW} / \mathrm{m}^{2}$ and $25,000 \mathrm{~kW} / \mathrm{m}^{2}$. As per previous experiments, internal and external temperatures were recorded as well as air toxics to determine if the system meets tenability and surviviability requirements.

Outside temperatures at $1 \mathrm{~m}$ peaked at around $800^{\circ} \mathrm{C}$ for all three experiments. The inside air temperature peaked at around $50^{\circ} \mathrm{C}$ for the $10,000 \mathrm{~kW} / \mathrm{m}^{2}$ and $15,000 \mathrm{~kW} / \mathrm{m}^{2}$ experiments and $70^{\circ} \mathrm{C}$ at the cabin ceiling $\left(50^{\circ} \mathrm{C}\right.$ at seat height $)$ in the $25,000 \mathrm{~kW} / \mathrm{m}^{2}$ experiment.

For the medium tanker at $10,000 \mathrm{~kW} / \mathrm{m}^{2}$ and $15,000 \mathrm{~kW} / \mathrm{m}^{2}$ resulted in no survivabilty criteria being exceeded for the truck cabin with the exception of respirable particles. For the $25,000 \mathrm{~kW} / \mathrm{m}^{2}$ test, the tanker was compromised by the earlier experiments (Figure 4) and exhibited more failures to tenability and survivability, though a less extensive range of air toxics were measured.

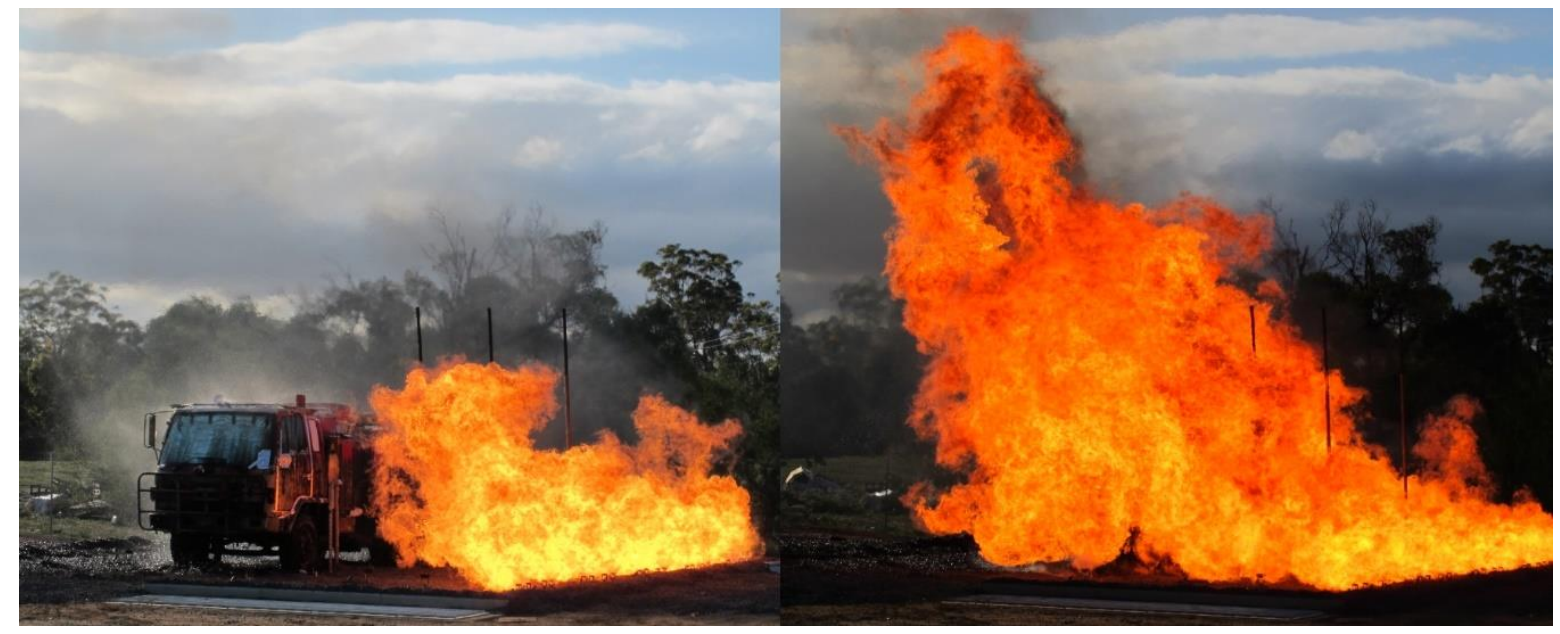

Figure 4. CFA Medium tanker on the flame front simulator during the 25,000kW/m2 Mogo, NSW, experiment

\subsubsection{CAFS ultra-light tanker test}

The outside temperatures at $1 \mathrm{~m}$ high peaked at $800^{\circ} \mathrm{C}$, while inside the cabin peaked at $50^{\circ} \mathrm{C}$. For air toxics, respirable particles increased at flame immersion, and exceeded tenability and survivability criteria. There was a significant fire that developed in the engine compartment following flame immersion which would have caused an increase to carbon monoxide levels and respirable particles. While there was no visible damage to the cabin interior, the delayed air toxic build up was evident and consistent with a late-stage engine compartment fire (Leonard et al., 2017). 


\section{Summary of results}

\subsection{Wangaratta grass fire experiments}

The medium tanker and gel ultra-light crew protection systems passed all tenability and survivability objectives.

\subsection{Brucknell forest fire experiment}

The medium tanker and CAFS ultra-light tankers passed all tenabilty and survivability objectives. The gel ultra-light passed the immediate test, however the cabin did become untenable during the latter stage of the experiment. However, cabins only need to be tenable as the fire front passes through, at this stage fire fighters can leave the cabin and seek refuge on burnt ground.

\subsection{Mogo flame front simulator}

The test confirmed that the medium tanker crew protection systems are robust enough at even the highest level of $25,000 \mathrm{~kW} / \mathrm{m}^{2}$ fireline intensity with cabin air temperatures remaining at survivable levels. At $25,000 \mathrm{~kW} / \mathrm{m}^{2}$ the cabin was compromised before the experiment began due to damage in earlier tests; and the truck exhibited more significant failures of air toxicity tenability and survivability. At the lower intensities $\left(10,000 \mathrm{~kW} / \mathrm{m}^{2}\right.$ and $\left.15,000 \mathrm{~kW} / \mathrm{m}^{2}\right)$ no survivability criteria was exceeded with the exception of respirable particles.

For the CAFS ultra-light tanker experiment at $5,000 \mathrm{~mW} / \mathrm{m}^{2}$, the cabin air temperature remained survivable throughout the test. No air toxicity survivablility criteria was exceeded within the cabin with the exception of respirable particles.

\section{Discussion}

On 7 February 2009, Victoria experienced unprecedented extremes in fire weather resulting in the Black Saturday wildfires. 173 people perished, over 2000 properties were lost and over 430,000 hectares were burnt. Twenty-nine fire fighting vehicles were burn over by wildfire, but remarkably no fire fighters were seriously injured (Nichols, 2010). A number of the fire fighting crews caught out in these burn overs praised the equipment and safety measures made available to them (Royal Commission into Victoria's Bushfires, 2010).

In 2014 the Australasian Fire and Emergency Services Authority Council (AFAC) identified three principles in the guideline for Rural Fire fighting Vehicles Burn over Protection (AFAC, 2015):

1. Ensure the fire fighting vehicle is designed to keep moving so that it does not become disabled or otherwise prevented from escaping to a safe zone.

2. Ensure that the operational functionality of the fire fighting vehicle is not compromised and that the safety support systems and other critical equipment continue to function.

3. Use the fire fighting vehicle to provide a refuge area for the fire fighters operating it.

These guidelines have been derived from the Australian research and development invested by CFA, Commonwealth Scientific and Industrial Research Organisation (CSIRO) and NSW RFS.

\section{Acknowledgements}

There were a number of people involved in muliple facets of this research. From CSIRO Land and Water: Lyndon Macindoe, Steve Brown and Glenn Newnham, who were responsible for the instrumentation and measurements at the Wangaratta, Brucknell and Mogo fire experiments. Richard Hurley, CSIRO Bushfire Research, for his weather and thermal instrumentation, and helpful direction of suppression crews. 
The EVTA Group consisting of Ross Luke, Brenton Luke and Mitch Luke whom designed and developed the Red Door Gel 'Crew Protection' System, alongside retired CFA engineer Robert Rankin. CFA engineer Andrew Webb and mechanic Peter Hill worked with Bell Engineering to design the Compressed Air Foam (CAFS) ultra-light crew protection system.

NSW RFS for the use of the Mogo facility. And to all CFA members who assisted with finding the land and providing appropriate fire suppression support to enable the experimental burns to occur.

\section{References}

Australiasian Fire and Emergency Services Authority Council (2015) Rural Firefighting Vehicles Burn-over Protection Guideline Version 1.0 March, 2015.

Cheney, N.P., Gould, J.S., and McCaw, L. (2001) The Dead-Man Zone - A neglected area of firefighter safety Australian Forestry 64(1), 45-50.

Corners Court of Victoria (2002) Report on the investigation and inquest into a wildfire and deaths of five firefighters at Linton on 2 December 1998. Report by the State of Victoria, January 2002.

Country Fire Authority (1983) The major fires originiating 16th February 1983. Report by CFA, December 1983.

Country Fire Authority and Natural Resource and Environment (1999) Report on the operations review of Linton fire/Midland fire \#15 on Wednesday 2nd December 1998. Operations review team report, March 1999.

Cruz, M.G., Gould, J., Kidnie, S., Nichols, D., Anderson, W., Bessell, R., Hurley, R., Koul, V., (2014) Grass Curing and Fire Behaviour. CSIRO Report (EP146628) prepared for CFA, August 2014.

Cruz, M.G., Hurley, R., Bessell, R., Nichols, D. (2016) Brucknell vehicle burn trial - report on fuels, weather and fire behaviour. CSIRO Report prepared for CFA, June 2016.

Leonard, J., Macindoe, L., Brown, S.K. (2013) Ultra-light Fire Tanker Gel Burnover Assessment May 2013. CSIRO Report prepared for CFA, May 2013.

Leonard, J., Macindoe, L., Brown, S.K. (2014) Fire Tanker Grassfire Burnover Assessments May 2014. CSIRO Report prepared for CFA, May 2014.

Leonard, J., Macindoe, L., Brown, S.K., Newnham, G. (2016) Fire Tanker Bushfire Assessment 2016. CSIRO Report prepared for CFA, March 2016.

Leonard, J., Newnham, G., Blanchi, R., Brown, S., McIndoe, L. (2017) CFA Ultra-light Fire Tanker CAFS Burnover Assessment. Mogo NSW - 23rd November 2017. CSIRO Report (EP181372) prepared for CFA, November 2017.

Leonard, J., Newnham ,G., Blanchi, R., Brown, S., MacIndoe, L. (2018) CFA ISUZU Fire Tanker Burnover Spray Assessment 2017, 1 CSIRO Report (EP183195) prepared for CFA, June 2018.

Nichols, D. (2010) Wildfire Vehicle Crew Protection. Conference Proceedings VI International Conference on Forest Fire Research, November 2010.

Reisen, F. \& Brown, S.K. (2009) Australian firefighters' exposure to air toxics during bushfire burns of autumn 2005 and 2006. Environment International 35 (2), 342-352.

Royal Commission into Victoria's Bushfires, McLeod, R. N., Pascoe, S. M., \& Teague, B. G. (2010). Final report. [Melbourne]: Government Printer for the State of Victoria. 